\title{
Genetic Structure and Molecular Variability Analysis of Citrus sudden death-associated virus Isolates from Infected Plants Grown in Brazil
}

\author{
Emilyn Emy Matsumura ${ }^{1,2}$, Helvécio Della Coletta Filho ${ }^{2}$, Silvia de Oliveira Dorta ${ }^{2}$, \\ Shahideh Nouri ${ }^{3}$ and Marcos Antonio Machado ${ }^{2, *}$ \\ 1 Instituto de Biociências de Botucatu, Universidade Estadual Paulista, Botucatu, São Paulo 03178-200, Brazil; \\ emilyn.matsumura@gmail.com \\ 2 Laboratório de Biotecnologia, Centro de Citricultura Sylvio Moreira, Instituto Agronômico, Cordeiropolis, \\ SP 13490-970, Brazil; helvecio@centrodecitricultura.br (H.D.C.F.); dorta.silvia@gmail.com (S.d.O.D.) \\ 3 Department of Plant Pathology, University of California Davis, Davis, CA 95616, USA; \\ shahidehnr@gmail.com \\ * Correspondence: marcos@centrodecitricultura.br; Tel.: +55-19-3546-1399
}

Academic Editor: Thomas Hohn

Received: 13 October 2016; Accepted: 10 December 2016; Published: 16 December 2016

\begin{abstract}
Citrus sudden death-associated virus $(\mathrm{CSDaV})$ is a monopartite positive-sense single-stranded RNA virus that was suggested to be associated with citrus sudden death (CSD) disease in Brazil. Here, we report the first study of the genetic structure and molecular variability among $31 \mathrm{CSDaV}$ isolates collected from both symptomatic and asymptomatic trees in CSD-affected areas. Analyses of partial nucleotide sequences of five domains of the CSDaV genomic RNA, including those encoding for the methyltransferase, the multi-domain region (MDR), the helicase, the RNA-dependent RNA polymerase and the coat protein, showed that the MDR coding region was the most diverse region assessed here, and a possible association between this region and virus adaption to different host or plant tissues is considered. Overall, the nucleotide diversity $(\pi)$ was low for CSDaV isolates, but the phylogenetic analyses revealed the predominance of two main groups, one of which showed a higher association with CSD-symptomatic plants. Isolates obtained from CSD-symptomatic plants, compared to those obtained from asymptomatic plants, showed higher nucleotide diversity, nonsynonymous and synonymous substitution rates and number of amino acid changes on the coding regions located closer to the 5' end region of the genomic RNA. This work provides new insights into the genetic diversity of the $\mathrm{CSDaV}$, giving support for further epidemiological studies.
\end{abstract}

Keywords: citrus sudden death; CSDaV; plant virus; Marafivirus; diversity

\section{Introduction}

Citrus sudden death-associated virus (CSDaV) is a member of the genus Marafivirus in the family Tymoviridae, and has shown a strong association with Citrus sudden death (CSD), an important citrus disease in Brazil [1]. CSDaV virions are isometric particles of $\approx 30 \mathrm{~nm}$ in diameter, composed of a monopartite, positive-sense, single-stranded RNA genome of approximately $6.8 \mathrm{~kb}$ with a high cytosine content $(37.4 \%$ ) and encompassing two ORFs [1,2]. A large ORF (ORF1) encodes a $240 \mathrm{kDa}$ polyprotein ( $\mathrm{p} 240$ ) which contains conserved signatures of domains involved with replication and virion structure, including the methyltransferase (MT), the papain-like protease (PRO), the helicase (He), the RNA-dependent RNA polymerase (RdRP) domains and two subunits of the coat protein $(\mathrm{CP})$ of 21 and $22 \mathrm{kDa}$ in size, respectively [1]. Moreover, a multi-domain region that contains numerous predicted single domains is detected in ORF1 (between the MT and PRO domains), but the function of this region in CSDaV is unknown. The small ORF (ORF 2) at the 3' end region encodes a $16 \mathrm{kDa}$ putative 
protein (p16) that has shown $42 \%$ identity with the N-terminal portion of a putative movement protein (p31) from Grapevine fleck virus (GFkV), a member of the genus Maculavirus in the family Tymoviridae [1].

The first report of CSD was in 1999, affecting sweet oranges (Citrus sinensis L. Osb.) grafted on Rangpur lime rootstock (Citrus limonia L. Osb.), the main non-irrigated rootstock used in Brazil [3]. Since then, CSD has caused death or eradication of four million orange trees in Minas Gerais and São Paulo states [4]. Recently, CSD-symptoms have been also detected in sweet oranges grafted on other rootstocks (e.g., Citrus volkameriana, Citrus jambiri and Citrus pennivisiculata Lush) [5]. Citrus plants affected by CSD show general decline symptoms characterized by pale green coloration of leaves, different levels of defoliation, death of the root system, and a characteristic development of yellow stain in the phloem of the rootstock [6], which is the main diagnostic symptom of this disease $[3,6]$. However, these affected plants had an incubation period of at least 2 years before symptoms were detected [1,6], which may result in delay of management of the disease. Although the etiology of CSD has not been definitively determined, Maccheroni et al. [1] reported a significant correlation at 99.7\% between CSD symptoms and the presence of CSDaV, and suggested that it is probably spread by an aphid vector. The presence of $\mathrm{CSDaV}$ as a part of a multiple virus infections or co-infections has been reported in other hosts as well, such as in Pinot Noir grapevine [7], in Nectarine [8] and in grapevine Syrah showing decline symptoms [9]. Such co-infections are also considered for plants showing CSD symptoms $[1,4,10]$.

Only two CSDaV isolates have been characterized so far, and their complete genome sequences are available in GenBank (accession No. AY884005 and DQ185573). However, the structure of CSDaV populations has not been studied and the evolutionary forces that may shape this structure are still unknown. To better understand the relationship between CSDaV and CSD, we studied the genetic structure and molecular variability among CSDaV isolates obtained from CSD-affected areas, and compared them with reference isolates by analyzing the partial nucleotide sequences of five coding regions including those for $\mathrm{MT}$, the multi-domain region (named here as MDR), the He, the RdRP and the CP. As a result, we showed that the MDR region was the most diverse region assessed here. We identified the predominance of two main phylogenetic groups, one of which showed a higher association with CSD-symptomatic plants. CSDaV isolates from CSD-symptomatic plants showed higher nucleotide diversity, nonsynonymous and synonymous substitution rates and number of amino acid changes on the coding regions located closer to the $5^{\prime}$ end region of the genomic RNA. These results provide relevant information for further epidemiological studies.

\section{Materials and Methods}

\subsection{Plant Collection}

The CSDaV population was assessed from different citrus plants: different cultivars of sweet orange grafted on different rootstocks, susceptible and tolerant to CSD. A total of 31 plants was sampled: fifteen trees were asymptomatic and 16 trees had clear CSD symptoms (i.e., occurrence of yellow stain in the rootstock bark), including a tree grafted on Sunki mandarin of China, which is supposed to be tolerant to CSD, and trees grafted on CSD-susceptible rootstock (Rangpur lime), but intergrafted with tolerant rootstocks (Trifoliate orange and Cleopatra mandarin). Genotypes and symptom information are summarized in Table 1. All selected trees were monitored since 2003 in CSD-affected areas located in the municipalities of Colombia (northern Sao Paulo State) and Comendador Gomes (southwestern Minas Gerais state), Brazil. CSD-symptomatic plants showed the first symptoms in 2006. All citrus plants were approximately five years old at the time of collection in 2007. Collected samples were frozen in liquid nitrogen and stored at $-80{ }^{\circ} \mathrm{C}$ prior to analysis. 
Table 1. Citrus plants used to assess the population of CSDaV. Canopy and rootstock genotypes of each plant are shown. Type of plant tissue and number of collected plants are indicated.

\begin{tabular}{|c|c|c|c|c|}
\hline & Canopy (C. sinensis) & Rootstock & $\begin{array}{l}\text { Collected } \\
\text { Tissue }\end{array}$ & $\begin{array}{l}\text { Number } \\
\text { of Plants }\end{array}$ \\
\hline \multirow{8}{*}{$\begin{array}{l}\text { Asymptomatic } \\
\text { plants }\end{array}$} & Natal & Rangpur lime (C. limonia) & Leaves & 1 \\
\hline & Valencia & Swingle citrumelo (P. trifoliate $\times$ C. paradisi) & Leaves & 3 \\
\hline & Hamlin & Rangpur lime (C. limonia) & Leaves & 3 \\
\hline & Pera Rio & Gou Tou (unidentified Citrus hybrid) & Leaves & 1 \\
\hline & Valencia & Cleopatra mandarin (C. reshni) & Leaves & 2 \\
\hline & Valencia & Trifoliate orange $(P$. trifoliata $)$ & Leaves & 3 \\
\hline & Hamlin & Cleopatra mandarin (C. reshni) & Leaves & 1 \\
\hline & Hamlin & Cleopatra mandarin (C. reshni) & Roots & 1 \\
\hline \multirow{9}{*}{$\begin{array}{l}\text { Symptomatic } \\
\text { plants }\end{array}$} & Valencia & Volkamerian lemon (C. volkameriana) & Leaves & 1 \\
\hline & Natal & Rangpur lime (C. limonia) & Leaves & 2 \\
\hline & Hamlin & Rangpur lime (C. limonia) & Leaves & 2 \\
\hline & Hamlin & Volkamerian lemon (C. volkameriana) & Leaves & 1 \\
\hline & Valencia & $\begin{array}{l}\text { Rangpur lime (C. limonia) and Trifoliate } \\
\text { orange }(P . \text { trifoliata }) \text { as interstock }\end{array}$ & Leaves & 2 \\
\hline & Pera Rio & Rangpur lime (C. limonia) & Leaves & 3 \\
\hline & Hamlin & $\begin{array}{l}\text { Rangpur lime (C. limonia) and Cleopatra } \\
\text { mandarin }(\text { C. reshni) as interstock }\end{array}$ & Leaves & 2 \\
\hline & Hamlin & Rangpur lime (C. limonia) & Roots & 2 \\
\hline & Valencia & Sunki mandarin of China (C. sunki) & Leaves & 1 \\
\hline & & Total $=31$ plants & & \\
\hline
\end{tabular}

\subsection{RNA Extraction and RT-PCR Amplification}

Total RNA was extracted from all samples using the RNeasy Plant Mini kit (Qiagen, Valencia, CA, USA) according to the manufacturer's instructions. A set of primers (Table 2) was designed to amplify nucleotide sequences, which corresponded partially to the five domains: the methyltransferase (MT), the multi-domain region (MDR), the helicase (He), the RNA-dependent RNA polymerase (RdRP) and the coat protein $(\mathrm{CP})$ coding regions based on the CSDaV reference genomes (GenBank accession no. AY884005 and DQ185573) (Figure 1). cDNAs were synthesized in a $20 \mu \mathrm{L}$ volume of $1 \times$ Reaction Buffer, containing $0.5 \mathrm{mM}$ dNTPs mix, $200 \mathrm{U}$ of RevertAid H Minus M-MuLV Reverse Transcriptase (Thermo Scientific, Waltham, MA, USA), and $5 \mu \mathrm{M}$ of a random hexamer primer. PCR reactions were performed in $25 \mu \mathrm{L}$ volume, containing $1 \times$ High Fidelity PCR Buffer (Invitrogen, Carlsbad, CA, USA), $0.2 \mathrm{mM}$ dNTP mix, $2 \mathrm{mM} \mathrm{MgSO} 4,0.02 \mathrm{U}$ of Platinum Taq DNA Polymerase High Fidelity (Invitrogen) and $10 \mathrm{mM}$ of each forward and reverse primers. The following PCR conditions were used: $94{ }^{\circ} \mathrm{C}$ for $2 \mathrm{~min}$; 35 cycles each of $94{ }^{\circ} \mathrm{C}$ for $15 \mathrm{~s}, 55^{\circ} \mathrm{C}$ (for all pair of primers) for $30 \mathrm{~s}$ and $68^{\circ} \mathrm{C}$ for $1 \mathrm{~min}$. The resulted PCR products were separated by electrophoresis in a $1 \%$ agarose gel and detected by ethidium bromide staining. Bands were cut from the gel and the PCR products were purified using a QIAquick gel extraction kit (Qiagen).

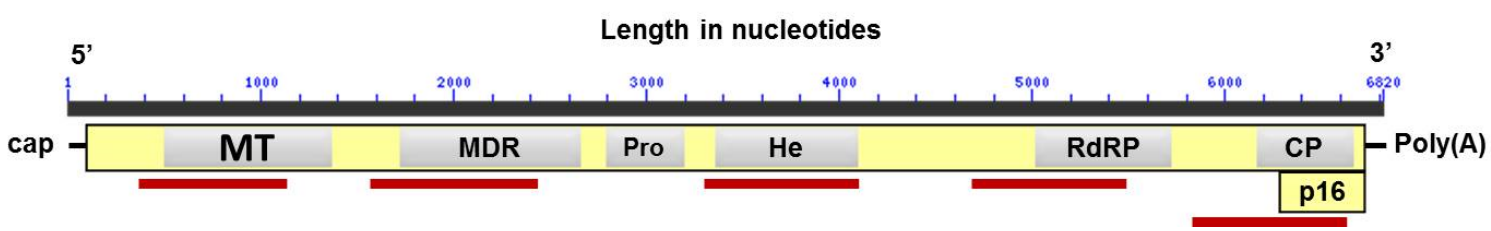

Figure 1. Genome organization of CSDaV. The two ORFs are represented by yellow boxes and the conserved domains are represented by grey boxes. Red bars indicate the genomic regions analyzed in this study. 
Table 2. Primer sequences designed based on five genomic regions of CSDaV genome.

\begin{tabular}{ccc}
\hline Genomic Region & Primer Sequences (5' $\left.^{\prime} \mathbf{3}^{\prime}\right)$ & Annealing Nucleotide Position \\
\hline \multirow{2}{*}{ MT } & Forward-CGTCAAACTCCCNCTGAC & $351-368$ \\
& Reverse-GATCANNAGAGAGTGGACTG & $1094-1113$ \\
\hline \multirow{2}{*}{ MDR } & Forward-CTCCCTCTCCATCTGCAAGC & $1566-1585$ \\
& Reverse-ATANTCNNTGGAGGGGTCA & $2375-2393$ \\
\hline \multirow{2}{*}{ He } & Forward-AGATNTTGGCNCTNGANTC & $3305-3323$ \\
& Reverse-ANTCNGAGAACATTCNGTTG & $4092-4111$ \\
\hline \multirow{2}{*}{ RdRP } & Forward-CATCAAGAGAANCANGANCC & $4636-4355$ \\
& Reverse-TGAGACCATAGTGGGAGTGT & $5414-5433$ \\
\hline \multirow{2}{*}{ CP } & Forward-GCCATCTACACCACACTCTC & $5857-5876$ \\
& Reverse-TTGGANTAGACGGAGTAGGA & $6568-6587$ \\
\hline
\end{tabular}

\subsection{Cloning and Sequencing}

The purified PCR products were cloned into pGEM-T vector (Promega, Madison, WI, USA) using T4 DNA ligase (Promega) according to the manufacturer's instructions, followed by transformation into Escherichia coli DH5 $\alpha$ competent cells [11]. Ten recombinant colonies were selected on screening media and confirmed by colony PCRs. Plasmid DNAs were extracted using the PureYield plasmid miniprep system kit (Promega) following the manufacturer's instructions and were bi-directionally sequenced using an Applied Biosystems 3730 DNA Analyzer.

\subsection{Nucleotide Sequence Analysis}

CSDaV reference sequences, identified as AY884005 (CSDaV) and DQ185573 (CSDaV strain p15) were downloaded from GenBank [12] and included in this analysis as representatives of CSDaV. Multiple nucleotide sequence alignments for each genomic region were obtained using the CLUSTAL W [13], and manually edited in the program MEGA 6.06 [14]. Neighbor joining phylogenetic trees were inferred with 1000 bootstraps in the MEGA 6.06 program and the generated trees were edited using FigTree version 1.4.2 [15]. A set of sequences for each genomic region of CSDaV were assessed using DnaSP software version 5.1 [16] to estimate genetic diversity and other population genetic parameters.

Recombination events among CSDaV isolates were examined using phylogenetic analysis and the boot-scan method in the SimPlot program [17]. Evidence of recombination was considered when $70 \%$ of permuted trees supported a particular grouping of sequences. The window width and the step size were set to 200 and $20 \mathrm{bp}$, respectively. The degree of selective constraints imposed on different regions of CSDaV genome was estimated with MEGA 6.06 program by analyzing the nonsynonymous and synonymous substitutions ratios $(\mathrm{dN} / \mathrm{dS}=\omega)$ using the Kumar method and bootstrap with 500 replicates [18]. Fixed effects likelihood (FEL), random effects likelihood (REL), and single likelihood ancestor counting (SLAC) tests, all included in the Hyphy package [19], were performed to determine the site specific selection pressure for the coding regions. For SLAC and FEL, the cut-off $p$-value was defined as 0.1 and for REL, a Bayes factor of 50 was selected as the cut-off value. Only positive selections determined by at least two methods were accepted [20].

\section{Results}

\subsection{Genetic Diversity of CSDaV Population}

The presence of CSDaV was confirmed immediately after plants collection in both symptomatic and asymptomatic plants, including trees grafted on the CSD tolerant rootstocks, such as Cleopatra and Sunki mandarins, Swingle citrumelo and Poncirus trifoliata. Two step RT-PCRs with specific degenerate primers sets (Table 2) generated amplicons with 762, 827, 806, 797, $730 \mathrm{bp}$ in length for the five regions 
of CSDaV genomic RNA including those encoding for the MT, the MDR, the He, the RdRp and the $\mathrm{CP}$, respectively [21]. Figures S1 and S2 and Tables S1 and S2 in the supplemental material show all conserved domains detected from conserved domain search using the CSDaV reference genomes as queries in the NCBI Conserved Domain Database (CDD). A total of 31 CSDaV isolates were obtained (Table 3) and the number of sequences for each region is illustrated in Table 4. Nucleotide diversities were estimated based on the number of segregating sites $(\theta \mathrm{w})$ and the average number of nucleotide differences per site between sequences $(\pi)$. Overall, the genetic diversity for CSDaV isolates evaluated in this study was low ranging from 0.01013 (the CP fragment) to 0.04185 (the He fragment) (Table 4) with a mean genetic diversity of 0.026118 .

Table 3. List of CSDaV sequences obtained in this work. Accession numbers in the GenBank database for the different genomic regions of each isolates are indicated.

\begin{tabular}{|c|c|c|}
\hline Isolate Identification * & Viral Genomic Region & GenBank Accession No. \\
\hline \multirow{3}{*}{ VAVK1D } & MT & KX753236 \\
\hline & MDR & KX753259 \\
\hline & $\mathrm{CP}$ & KX753328 \\
\hline CR2D & MDR & KX753263 \\
\hline \multirow{3}{*}{ HAVK11D } & MT & KX753252 \\
\hline & MDR & KX753260 \\
\hline & $\mathrm{CP}$ & KX753326 \\
\hline \multirow{4}{*}{ NACR12D } & MT & KX753233 \\
\hline & MDR & KX753261 \\
\hline & RdRP & KX753309 \\
\hline & $\mathrm{CP}$ & KX753327 \\
\hline \multirow{4}{*}{ PRCR19D } & MT & KX753245 \\
\hline & MDR & KX753262 \\
\hline & RdRP & KX753306 \\
\hline & $\mathrm{CP}$ & KX753330 \\
\hline \multirow{3}{*}{ PRGTC20S } & MT & KX753254 \\
\hline & MDR & KX753264 \\
\hline & $\mathrm{CP}$ & KX753321 \\
\hline \multirow{5}{*}{ VASW23S } & MT & KX753248 \\
\hline & MDR & KX753265 \\
\hline & $\mathrm{He}$ & KX753296 \\
\hline & RdRP & KX753316 \\
\hline & $\mathrm{CP}$ & KX753340 \\
\hline \multirow{5}{*}{ PRCR24D } & MT & KX753234 \\
\hline & MDR & KX753266 \\
\hline & $\mathrm{He}$ & KX753292 \\
\hline & RdRP & KX753313 \\
\hline & $\mathrm{CP}$ & KX753336 \\
\hline \multirow{4}{*}{ HACL26D } & MT & KX753243 \\
\hline & MDR & KX753267 \\
\hline & RdRP & KX753307 \\
\hline & $\mathrm{CP}$ & KX753323 \\
\hline \multirow{5}{*}{$\mathrm{CR}_{8} \mathrm{D}^{1}$} & MT & KX753257 \\
\hline & MDR & KX753268 \\
\hline & $\mathrm{He}$ & KX753297 \\
\hline & RdRP & KX753318 \\
\hline & $\mathrm{CP}$ & KX753342 \\
\hline
\end{tabular}


Table 3. Cont.

\begin{tabular}{|c|c|c|}
\hline Isolate Identification * & Viral Genomic Region & GenBank Accession No. \\
\hline \multirow{5}{*}{ VASW30S } & MT & KX753256 \\
\hline & MDR & KX753269 \\
\hline & $\mathrm{He}$ & KX753293 \\
\hline & $\operatorname{RdRP}$ & KX753299 \\
\hline & $\mathrm{CP}$ & KX753324 \\
\hline \multirow{4}{*}{ VASW31S } & MT & KX753242 \\
\hline & MDR & KX753270 \\
\hline & RdRP & KX753298 \\
\hline & $\mathrm{CP}$ & KX753319 \\
\hline \multirow{4}{*}{ HACL38S } & MT & KX753244 \\
\hline & MDR & KX753271 \\
\hline & RdRP & KX753301 \\
\hline & $\mathrm{CP}$ & KX753320 \\
\hline \multirow{4}{*}{ VATR39S } & MT & KX753255 \\
\hline & MDR & KX753272 \\
\hline & $\operatorname{RdRP}$ & KX753305 \\
\hline & $\mathrm{CP}$ & KX753322 \\
\hline \multirow{4}{*}{ HACR42S } & MT & KX753241 \\
\hline & MDR & KX753273 \\
\hline & $\operatorname{RdRP}$ & KX753302 \\
\hline & $\mathrm{CP}$ & KX753333 \\
\hline \multirow{5}{*}{ CLBR43S $^{2}$} & MT & KX753251 \\
\hline & MDR & KX753274 \\
\hline & $\mathrm{He}$ & KX753294 \\
\hline & $\operatorname{RdRP}$ & KX753317 \\
\hline & $\mathrm{CP}$ & KX753334 \\
\hline \multirow{3}{*}{ VACL44S } & MT & KX753247 \\
\hline & MDR & KX753275 \\
\hline & $\mathrm{CP}$ & KX753341 \\
\hline \multirow{3}{*}{ VATR45S } & MT & KX753239 \\
\hline & MDR & KX753276 \\
\hline & $\mathrm{CP}$ & KX753332 \\
\hline \multirow{5}{*}{ VATR47D } & MT & KX753253 \\
\hline & MDR & KX753277 \\
\hline & $\mathrm{He}$ & KX753291 \\
\hline & RdRP & KX753314 \\
\hline & $\mathrm{CP}$ & KX753343 \\
\hline \multirow{3}{*}{$\mathrm{SKCH}_{5} \mathrm{D}^{3}$} & MT & KX753237 \\
\hline & MDR & KX753278 \\
\hline & RdRP & KX753310 \\
\hline \multirow{4}{*}{ VATR50S } & MT & KX753249 \\
\hline & MDR & KX753279 \\
\hline & RdRP & KX753312 \\
\hline & $\mathrm{CP}$ & KX753329 \\
\hline \multirow{4}{*}{ VATR51D } & MT & KX753258 \\
\hline & MDR & KX753280 \\
\hline & RdRP & KX753304 \\
\hline & $\mathrm{CP}$ & KX753325 \\
\hline \multirow{2}{*}{ HACL52D } & MDR & KX753281 \\
\hline & RdRP & KX753315 \\
\hline
\end{tabular}


Table 3. Cont.

\begin{tabular}{|c|c|c|}
\hline Isolate Identification * & Viral Genomic Region & GenBank Accession No. \\
\hline \multirow{2}{*}{ HACR55S } & MDR & KX753282 \\
\hline & $\mathrm{CP}$ & KX753331 \\
\hline \multirow{2}{*}{ HACR56D } & MT & KX753235 \\
\hline & MDR & KX753283 \\
\hline \multirow{2}{*}{ HACR58D } & MT & KX753250 \\
\hline & MDR & KX753284 \\
\hline \multirow{2}{*}{ NACR6D } & MT & KX753232 \\
\hline & MDR & KX753285 \\
\hline \multirow{5}{*}{ VACL25S } & MT & KX753238 \\
\hline & MDR & KX753286 \\
\hline & $\mathrm{He}$ & KX753289 \\
\hline & RdRP & KX753300 \\
\hline & $\mathrm{CP}$ & KX753337 \\
\hline \multirow{5}{*}{ NACR22S } & MT & KX753246 \\
\hline & MDR & KX753287 \\
\hline & $\mathrm{He}$ & KX753295 \\
\hline & RdRP & KX753308 \\
\hline & $\mathrm{CP}$ & KX753339 \\
\hline \multirow{5}{*}{ HACR41S } & MT & KX753240 \\
\hline & MDR & KX753288 \\
\hline & $\mathrm{He}$ & KX753290 \\
\hline & RdRP & KX753303 \\
\hline & $\mathrm{CP}$ & KX753338 \\
\hline \multirow{3}{*}{ PRCR16D } & MT & KX753231 \\
\hline & RdRP & KX753311 \\
\hline & $\mathrm{CP}$ & KX753335 \\
\hline
\end{tabular}

* Isolates were designated based on the citrus genotype from where the CSDaV isolates were obtained. First two letters identify the type of canopy (VA: Valencia; HA: Hamlin; PR: Pera Rio and NA: Natal), followed by the type of rootstock or interstock (VK: Volkameriano lemon; CR: Rangpur lime; GTC: Goutou; SW: Swingle citrumelo; CL: Cleopatra mandarin; TR: Trifoliate orange), the sample number and the symptom information (S: asymptomatic plant and D: symptomatic plant). ${ }^{1}$ Isolate from Rangpur lime rootstock tissues; ${ }^{2}$ Isolate from Cleopatra mandarin rootstock tissues; ${ }^{3}$ Isolate from leaves of Valencia grafted on Sunki mandarin of China.

Table 4. Population genetic parameters estimated for five coding regions of CSDaV isolates using the DnaSP and MEGA programs.

\begin{tabular}{ccccccccc}
\hline $\begin{array}{c}\text { Genomic } \\
\text { Regions }\end{array}$ & $\begin{array}{c}\text { Number of Final } \\
\text { Sequences }\end{array}$ & $\mathbf{S}$ & $\boldsymbol{\eta}$ & $\boldsymbol{\pi}$ & $\boldsymbol{\theta w}$ & $\mathbf{d N}$ & $\mathbf{d S}$ & $\begin{array}{c}\boldsymbol{\omega} \\
(\mathbf{d N} / \mathbf{d S})\end{array}$ \\
\hline $\mathrm{MT}$ & 28 & 82 & 84 & 0.01815 & 0.0346 & $0.005 \pm 0.002$ & $0.054 \pm 0.010$ & 0.093 \\
$\mathrm{MDR}$ & 30 & 180 & 214 & 0.04091 & 0.07212 & $0.023 \pm 0.004$ & $0.097 \pm 0.012$ & 0.237 \\
$\mathrm{He}$ & 9 & 81 & 83 & 0.04185 & 0.05613 & $0.006 \pm 0.002$ & $0.153 \pm 0.020$ & 0.039 \\
$\mathrm{RdRP}$ & 21 & 70 & 72 & 0.01955 & 0.02895 & $0.001 \pm 0.001$ & $0.068 \pm 0.009$ & 0.015 \\
$\mathrm{CP}$ & 25 & 26 & 27 & 0.01013 & 0.01897 & $0.003 \pm 0.001$ & $0.026 \pm 0.007$ & 0.115 \\
\hline
\end{tabular}

S: Total number of segregating sites; $\eta$ : Total number of mutations; $\pi$ : Nucleotide diversity, average pairwise nucleotide difference per site; $\theta \mathrm{w}$ : Mutation rate estimated from $S$; $d \mathrm{~N}$ : The average number of pairwise differences per synonymous site; dS: The average number of pairwise differences per non-synonymous site. $\mathrm{dS}$ and $\mathrm{dN}$ were estimated by the Kumar method.

\subsection{Phylogenetic Relationships of CSDaV Isolates}

The sequences of four representative viruses from the genera Tymovirus (Turnip yellow mosaic virus-TYMV, NC_004063), Maculavirus (Grapevine fleck virus_GFkV, NC_003347) and Marafivirus (Maize rayado fino virus-MRFV, NC_002786; and Oat blue dwarf virus_OBDV, NC_001793) of the family Tymoviridae were obtained from GenBank and used as outgroups in the phylogenetic analysis of all 
regions except the MDR segment because this region of CSDaV did not show any homology with any genomic region of four Tymoviridae representatives. Because six isolates were detected as possible recombinants based on the topology of phylogenetic trees (see details in the recombination analysis section), the final trees were constructed after removing these recombinants. In general, the topology of the MT (Figure 2a), the MDR (Figure 2b), the He (Figure 2c) and the RdRP (Figure 2d) trees was similar and showed the presence of two main groups of CSDaV isolates assessed in this study with high supporting bootstrap values equal or higher than $83 \%$. The intra-group diversity was best illustrated in the MDR tree (Figure 2b). The topology of the CP tree was different, in which all CSDaV isolates formed a single un-resolved polytomy clade with a supporting bootstrap value of $99 \%$ (Figure 2e). For all phylogenetic trees, with the exception of the $\mathrm{CP}$, the main groups were clustered separately from the two CSDaV reference sequences. Divergence between CSDaV reference sequences (AY884005 and DQ185573 isolates) was observed in the MDR, He and RdRP trees (Figure 2b-d).
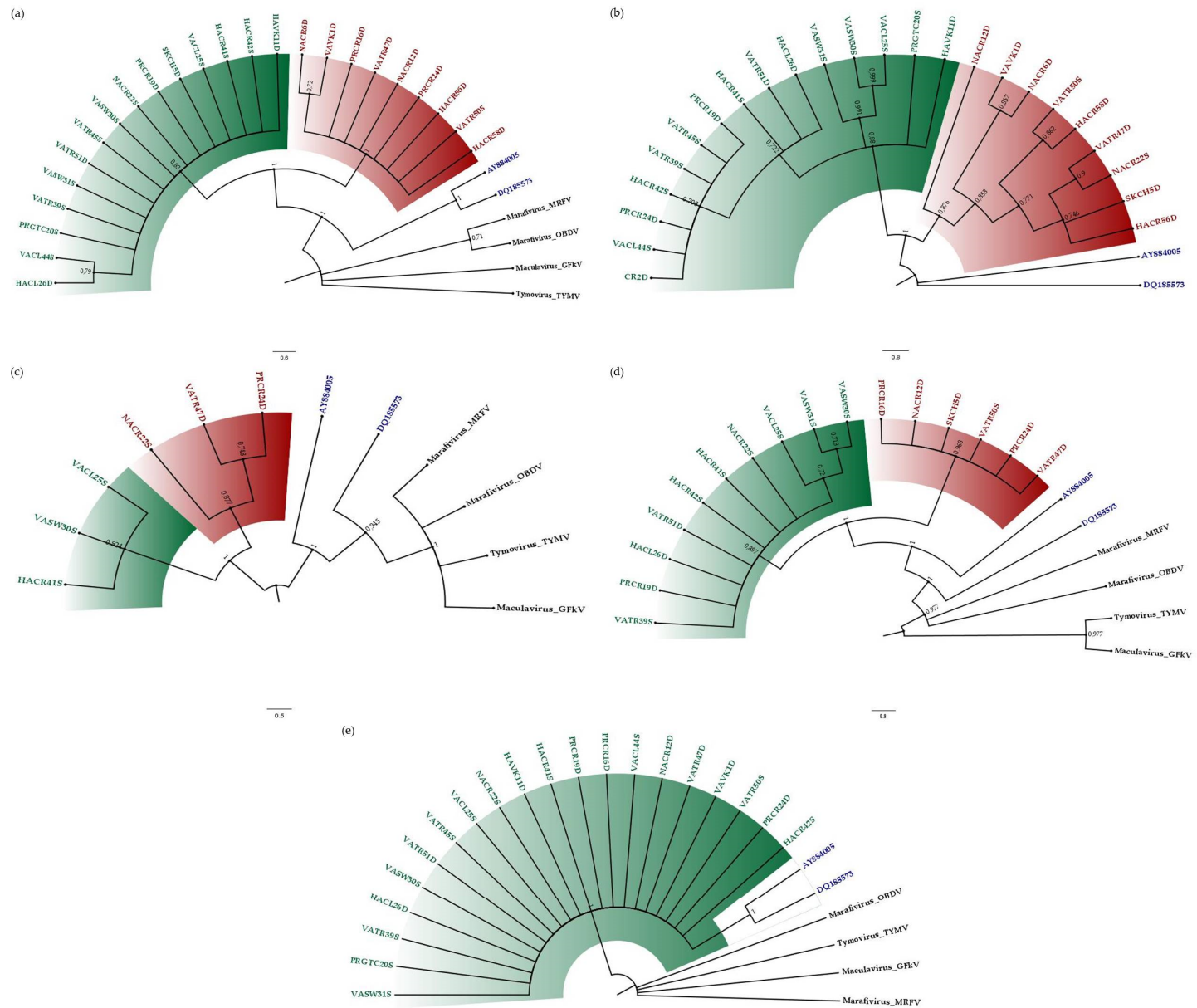

Figure 2. Bootstrap majority rule (70\%) consensus trees reconstructed by the neighbor joining method for five genomic regions of $\mathrm{CSDaV}$ isolates including field collected and reference sequences. Bootstrap support values (1000 iterations) of main branches are indicated. (a) MT segment; (b) MDR segment; (c) He segment; (d) RdRP segment; (e) CP segment. CSDaV groups are highlighted by different colors: Group I = green; Group II = red. The CSDaV reference isolates are represented in blue. The outgroups are represented in black. Isolates from asymptomatic plants are identified by letter $S$ at the end of their identification names. Isolates from symptomatic plants are identified by letter $\mathrm{D}$ at the end of their identification names. 


\subsection{Comparison of Genetic Diversity between Isolates from Asymptomatic and Symptomatic Plants}

Based on the MT, the MDR, the He and the RdRP phylogenetic trees, group I of the CSDaV isolates was formed by the majority of isolates from asymptomatic plants, whereas group II contained the majority of isolates from symptomatic plants (Figure 2 and Table 5). To further strengthen these results, CSDaV consensus sequences were obtained from transcriptome sequencing, conducted for both symptomatic and asymptomatic plants by using Illumina next generation sequencing (NGS) technology [22]. The coding regions studied here were accessed in these consensus sequences and included in the phylogenetic analysis. Based on the MT, the MDR, the He and the RdRP, the consensus sequence obtained from the asymptomatic library clustered close to the reference isolates, whereas the consensus sequence obtained from the symptomatic library was grouped in group II (Figure S3), which strongly supports the results presented above.

Table 5. Number of CSDaV sequences from symptomatic and asymptomatic plants between the two main phylogenetic groups assessed in this study.

\begin{tabular}{ccc}
\hline & \multicolumn{2}{c}{ Number of Isolates from Symptomatic Plants/Number of Isolates from Asymptomatic Plants } \\
\cline { 2 - 3 } & Group I $^{*}$ & Group II ** \\
\hline MT & $5 / 10$ & $8 / 1$ \\
MDR & $6 / 9$ & $7 / 2$ \\
He & $0 / 3$ & $2 / 1$ \\
RdRP & $3 / 7$ & $5 / 1$ \\
\hline
\end{tabular}

${ }^{*}$ Group I is highlighted in green in the phylogenetic trees (Figure 2); ** Group II is highlighted in red in the phylogenetic trees (Figure 2).

Compared to isolates from asymptomatic plants, the nucleotide diversities estimated only for isolates obtained from symptomatic plants were higher at about 2.2, 1.5, 1.1, 1.1 and 0.9 times for the MT, MDR, He, RdRP and CP regions, respectively (Table 6). The dN/dS ratio values were higher for the MDR region for isolates from both symptomatic and asymptomatic plants. However, this estimated value for the isolates from symptomatic plants was 1.4 times higher than the ratio estimated for the isolates from asymptomatic plants (Table 6). The deduced amino acid sequences from each CSDaV genomic region showed silent mutations between isolates from symptomatic and asymptomatic plants (Table 7).

Table 6. Comparison of the population genetic parameters estimated for five coding regions of $\mathrm{CSDaV}$ isolates from symptomatic (Symp.) and asymptomatic (Asymp.) plants using the DnaSP and MEGA programs.

\begin{tabular}{cccccccc}
\hline & Symptoms & Number of Sequences & $\boldsymbol{\pi}$ & $\boldsymbol{\theta w}$ & $\mathbf{d N}$ & $\mathbf{d S}$ & $\boldsymbol{\omega}$ \\
\hline \multirow{2}{*}{ MT } & Symp. & 13 & 0.01726 & 0.02117 & $0.007 \pm 0.002$ & $0.044 \pm 0.011$ & 0.159091 \\
& Asymp. & 11 & 0.00770 & 0.01402 & $0.002 \pm 0.001$ & $0.020 \pm 0.005$ & 0.100000 \\
\hline \multirow{2}{*}{ MDR } & Symp. & 13 & 0.03441 & 0.04143 & $0.026 \pm 0.005$ & $0.057 \pm 0.011$ & 0.456140 \\
& Asymp. & 11 & 0.02268 & 0.02601 & $0.014 \pm 0.004$ & $0.042 \pm 0.009$ & 0.333333 \\
\hline \multirow{2}{*}{ He } & Symp. & 2 & 0.00942 & 0.00942 & $0.002 \pm 0.002$ & $0.023 \pm 0.012$ & 0.086957 \\
& Asymp. & 4 & 0.00879 & 0.00924 & $0.003 \pm 0.002$ & $0.023 \pm 0.008$ & 0.130435 \\
\hline \multirow{2}{*}{ RdRP } & Symp. & 8 & 0.00856 & 0.00861 & $0.001 \pm 0.001$ & $0.026 \pm 0.008$ & 0.038462 \\
& Asymp. & 8 & 0.00787 & 0.00918 & $0.001 \pm 0.001$ & $0.024 \pm 0.007$ & 0.041667 \\
\hline \multirow{2}{*}{ CP } & Symp. & 9 & 0.00781 & 0.00912 & $0.003 \pm 0.001$ & $0.019 \pm 0.008$ & 0.157895 \\
& Asymp. & 11 & 0.00862 & 0.01317 & $0.004 \pm 0.002$ & $0.018 \pm 0.006$ & 0.222222 \\
\hline
\end{tabular}

$\pi$ : Nucleotide diversity, average pairwise nucleotide difference per site; $\theta \mathrm{w}$ : Mutation rate estimated from the total number of segregating sites; $\mathrm{dN}$ : The average number of pairwise differences per synonymous site; $\mathrm{dS}$ : The average number of pairwise differences per non-synonymous site. $\mathrm{dS}$ and $\mathrm{dN}$ were estimated by the Kumar method. 
Table 7. Amino acid changes in five CSDaV genomic regions in isolates obtained from symptomatic citrus plants compared to isolates obtained from asymptomatic citrus plants.

\begin{tabular}{|c|c|c|c|}
\hline Domain & $\begin{array}{l}\text { Number of Amino } \\
\text { Acid Changes }\end{array}$ & $\begin{array}{l}\text { Total Number of } \\
\text { Amino Acid }\end{array}$ & Position of Amino Acid Changes (Asymp $\rightarrow$ Symp) \\
\hline MT & 8 & 202 & $\begin{array}{c}13(\mathrm{I} \rightarrow \mathrm{T}) ; 57(\mathrm{P} \rightarrow \mathrm{Q}) ; 113(\mathrm{Q} \rightarrow \mathrm{R}) ; 144(\mathrm{~L} \rightarrow \mathrm{V}) ; 152\left(\mathrm{~S} \rightarrow{ }^{*}\right) \\
157(\mathrm{R} \rightarrow \mathrm{K}) ; 171(\mathrm{~A} \rightarrow \mathrm{V}) \text { and } 199(\mathrm{~T} \rightarrow \mathrm{I})\end{array}$ \\
\hline MDR & 10 & 209 & $\begin{array}{c}13(\mathrm{G} \rightarrow \mathrm{D}) ; 14(\mathrm{P} \rightarrow \mathrm{R}) ; 22(\mathrm{~L} \rightarrow \mathrm{A}) ; 29(\mathrm{I} \rightarrow \mathrm{T}) ; 103(\mathrm{~F} \rightarrow \mathrm{S}) ; \\
109(\mathrm{~F} \rightarrow \mathrm{S}) ; 110(\mathrm{Q} \rightarrow \mathrm{P} ; 187(\mathrm{~S} \rightarrow \mathrm{L}) ; 197(\mathrm{H} \rightarrow \mathrm{R}) \text { and } 209(\mathrm{Q} \rightarrow \mathrm{R})\end{array}$ \\
\hline $\mathrm{He}$ & 4 & 176 & $28(\mathrm{~V} \rightarrow \mathrm{A}) ; 62(\mathrm{~L} \rightarrow \mathrm{P}) ; 72(\mathrm{~T} \rightarrow \mathrm{I})$ and $120(\mathrm{M} \rightarrow \mathrm{I})$ \\
\hline RdRP & 4 & 223 & $37(\mathrm{P} \rightarrow \mathrm{L}) ; 136(\mathrm{~A} \rightarrow \mathrm{V}) ; 155(\mathrm{~N} \rightarrow \mathrm{S})$ and $200(\mathrm{~L} \rightarrow \mathrm{P})$ \\
\hline $\mathrm{CP}$ & 1 & 120 & $55(\mathrm{Q} \rightarrow \mathrm{R})$ \\
\hline
\end{tabular}

\subsection{Recombination Analysis}

Based on the phylogenetic trees constructed with all, including the possible recombinants CSDaV isolates (Figure S4), six isolates, named CR8D, CLBR43S, VASW23S, HACL38S, HACL52D and HACR55S showed some phylogenetic incompatibilities and evidence of recombination events. The two root isolates (CLBR43S and CR8D) clustered in the same clade according to the RdRP and the CP phylogenetic trees (Figure S4d,e), while they were placed separately based on the MT, the MDR and the He trees (Figure S4a-c). Isolate VASW23S grouped separately in MT and the RdRP phylogenetic trees (Figure S4a,d), but it clustered with the main groups in the MDR, the He and the CP trees (Figure S4b,c,e). Isolates HACL38S, HACL52D and HACR55S were not compared in all regions of the genome analyzed here because we were not able to obtain PCR products for all segments, and they were excluded from the recombination analysis. We selected nine representative isolates from this study including three suggested recombinants and six isolates representing the two main groups of $\mathrm{CSDaV}$, and two CSDaV reference sequences to concatenate their nucleotide sequences of the MT, the MDR, the He, the RdRP and the CP segments. Concatenated sequences were further analyzed using SimPlot. Both phylogenetic and Bootscan methods included in Simplot identified recombination signals as well as their possible parental sequences when VASW23S, CR8D and CLBR43S isolates were used as queries (Figures 3 and 4). Phylogenetic analysis of the concatenated sequences detected several recombination hotspots when different isolates were used as queries: positions 600 and 1322 when VASW23S isolate was used as the query (Figure 3a), positions 603, 1203 and 2458 when CR8D isolate was used as the query (Figure 3b) and positions 170 and 609 when CLBR43S isolate was used as the query (Figure 3c). On the other hand, Bootscan analyses demonstrated that the MDR and He segments of VASW23S isolate come from PRCR24D-like and VASW30S-like isolates, respectively (Figure 4a). For the CR8D isolate, a recombination event was detected by the Bootscan algorithm in which the MDR and He segments of CR8D were generated from two different origins: AY884005 and DQ185573 reference isolates, respectively (Figure $4 \mathrm{~b}$ ). When Bootscan analysis was performed using CLBR43S isolate as the query, we detected four recombination hotspots in which two of them were placed close to positions 170 and 619 (already shown by phylogenetic analysis), and two other hotspots were detected at positions 1271 and 1850 (Figures 3c and 4c). Furthermore, Bootscan results confirmed that the MDR and He segments of CLBR43S were generated from two CSDaV reference isolates (Figure 3c) and the region from the MT segment was likely driven by recombination events between a DQ185573 reference-like isolate and CR8D-like isolate. The RdRP and the CP segments from CLBR43S isolate showed phylogenetically inconsistent regions with some similarity with the CR8D isolate and the AY884005 reference isolate (Figure 4c). 
(a)

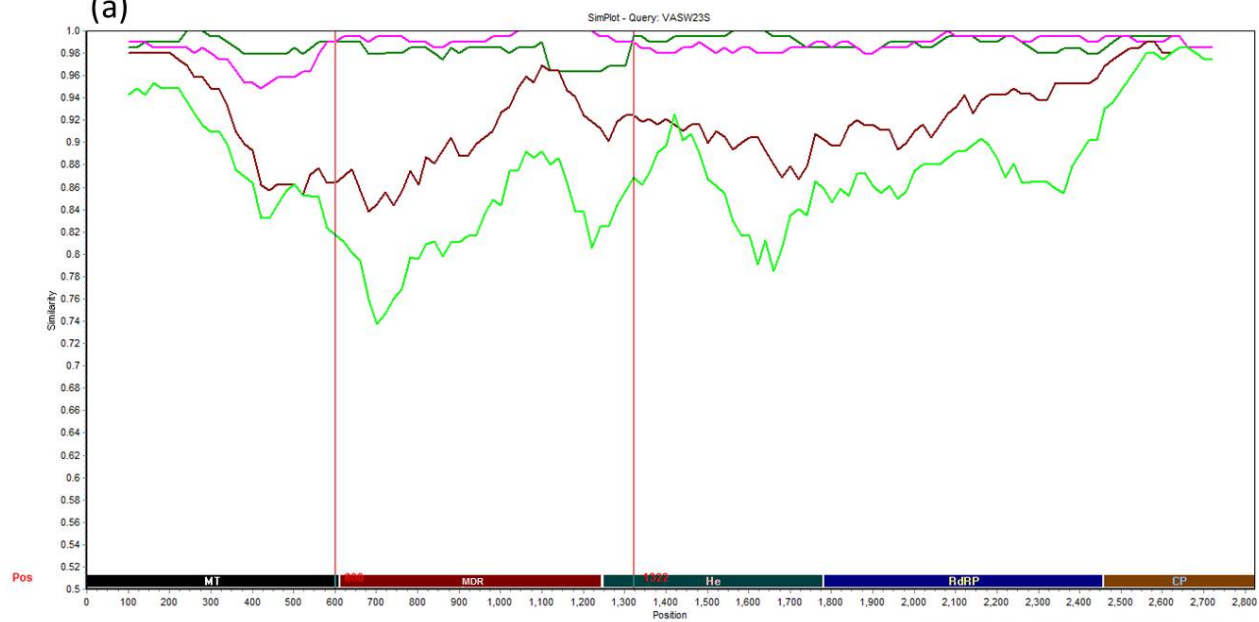

(b)

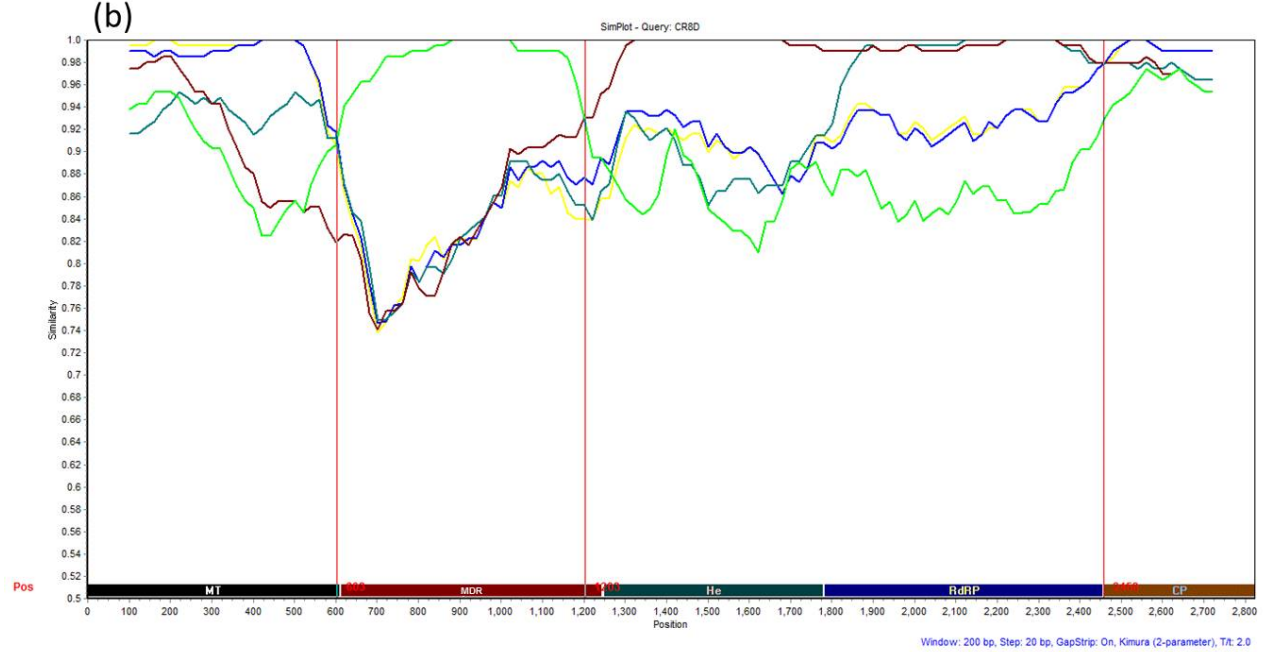

(c)

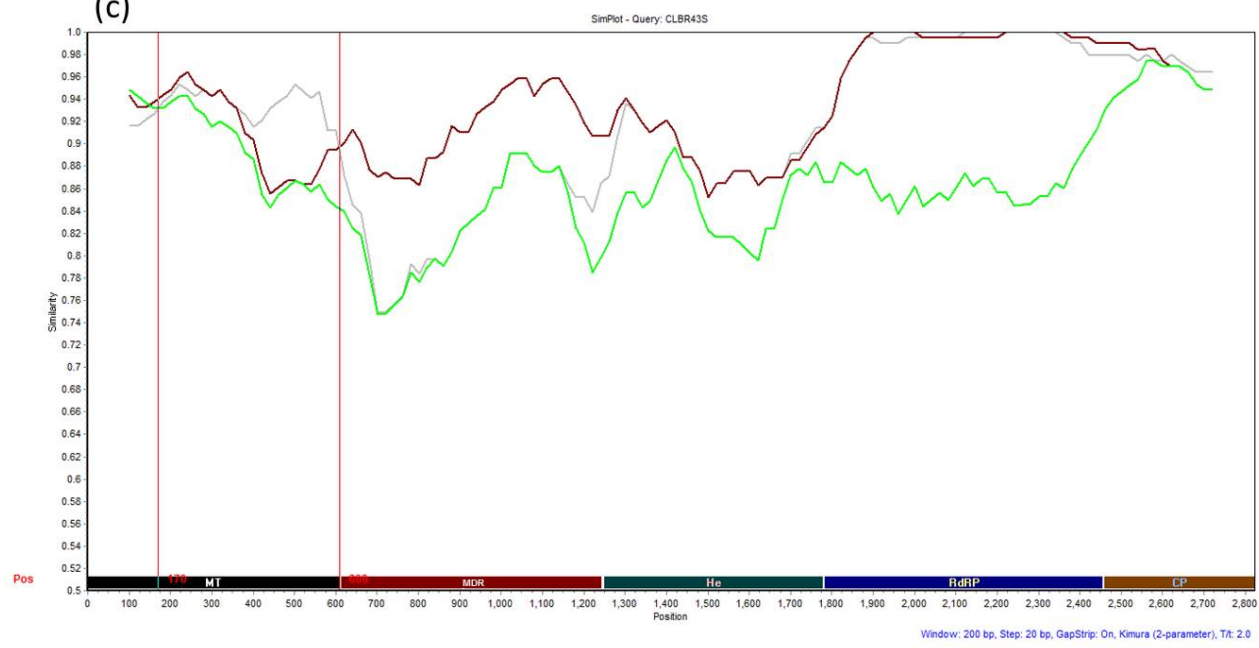

Figure 3. Phylogenetic relationship with potential recombinant $\mathrm{CSDaV}$ isolates as the query sequences based on concatenated nucleotide sequences of the MT, MDR, He, RdRP and CP genomic regions using Simplot. Three CSDaV isolates, VASW23S (a), CR8D (b) and CLBR43S (c), were used as query sequences and two CSDaV isolates were used as reference sequences. The Y-axis illustrates variation in identity percentage. Analyses were done using a sliding window of $200 \mathrm{bp}$ and a step size of $20 \mathrm{bp}$. Red vertical dashed line shows the proposed recombination break point. Sequences compared with the query sequence are indicated in the legend. 
(a)
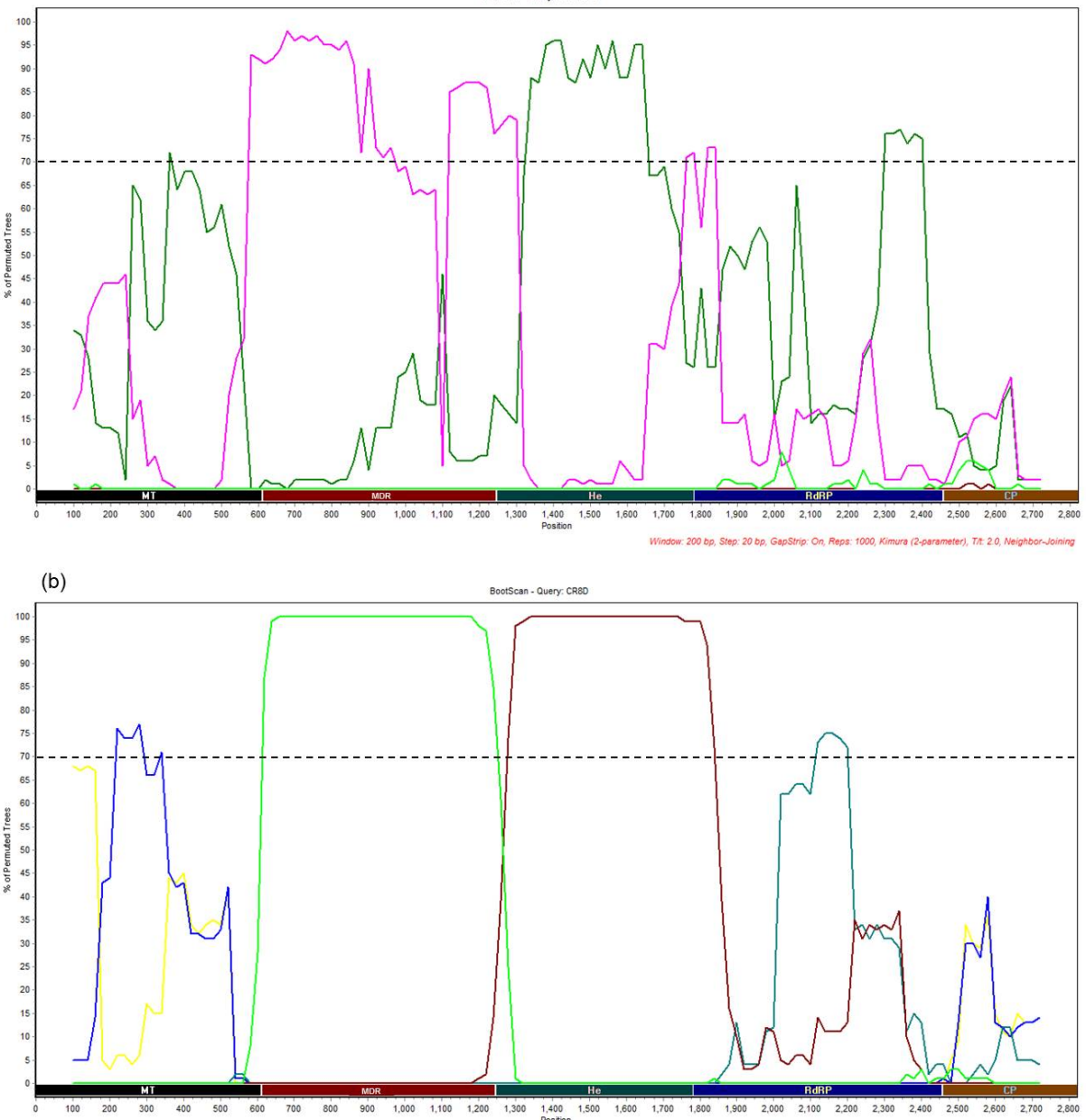

(c)
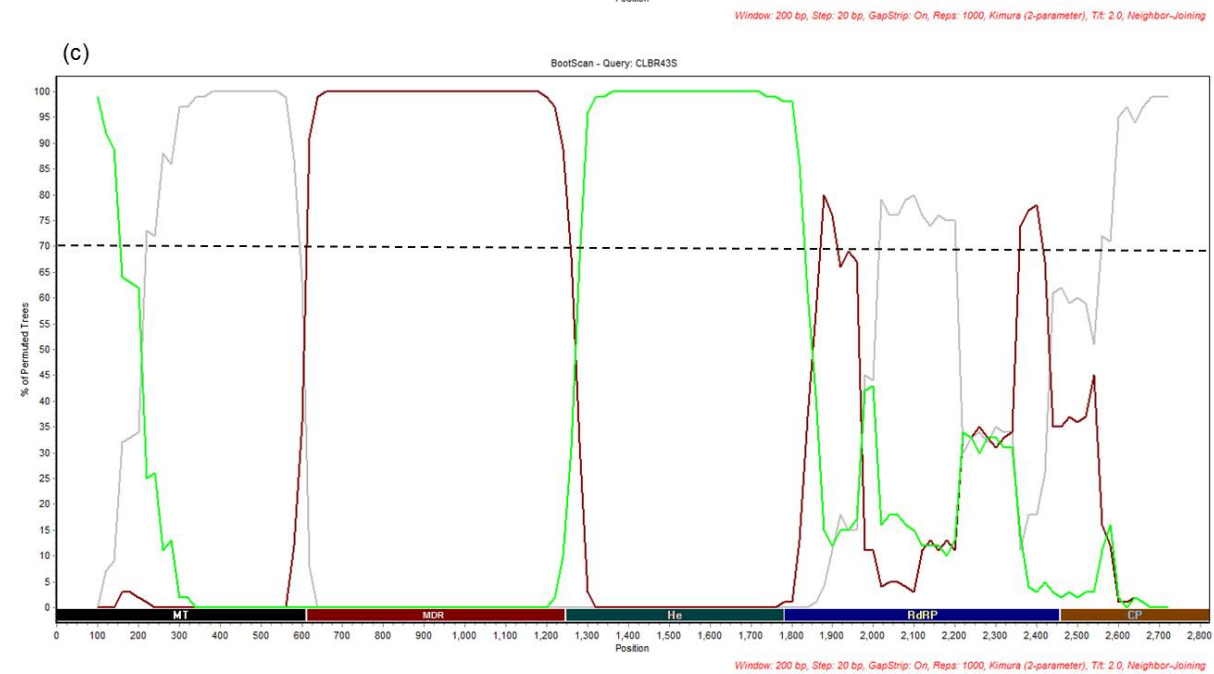

Figure 4. Bootscan analyses with potential recombinant CSDaV isolates as the query sequences based on concatenated nucleotide sequences of the MT, MDR, He, RdRP and CP genomic regions using Simplot. Three CSDaV isolates, VASW23S (a), CR8D (b) and CLBR43S (c), were used as query sequences and two CSDaV isolates were used as reference sequences. The Y-axis illustrates variation in percentage of permuted trees in which each selected isolate clustered with the query sequence. Analyses were done using a sliding window of $200 \mathrm{bp}$ and a step size of $20 \mathrm{bp}$. Black dashed line shows the $70 \%$ cutoff level, representing possible recombination. Sequences compared with the query sequence are indicated in the legend. 
Only the two root isolates detected as recombinants showed a close phylogenetic relationship to one of the CSDaV reference isolates: CR8D isolate in the MDR, the He and the RdRP trees and CLBR43S isolate in the RdRP tree (Figure S4). However, these isolates were phylogenetically distant from the main groups of CSDaV isolates assessed in this study. According to the MT, MDR, He and RdRP phylogenetic trees, isolate CLBR43S, obtained from tissues of Cleopatra mandarin rootstock, was found in a separate clade which was phylogenetically distant from the two main groups of CSDaV isolates (Figure S4). Similar results were found for isolate CR8D, obtained from a Rangpur lime rootstock, according to MDR, He and RdRP phylogenetic trees (Figure S4). Both of those separations were well-supported.

\subsection{Selective Pressure for Different Genomic Regions of CSDaV}

Evidence of positive selection was not found in any region of the genome for the CSDaV isolates included in this study. The mean $\omega(\mathrm{dN} / \mathrm{dS})$ value for all genomic regions analyzed here was less than 1.0, indicating that all segments were subjected to negative or purifying selection. Among regions, the MT, He, RdRP and CP regions showed low $\omega$ ratios, while this ratio was higher for the MDR region (Table 4). Moreover, complementary maximum-likelihood methods (SLAC, FEL and REL) detected positively selected sites only for the MDR segment. Site 20 in the MDR segment was considered to be significant under positive selection by two methods: FEL $(\mathrm{dN}-\mathrm{dS}=19.1017$ and $p$-value $=0.042)$ and REL methods $(\mathrm{dN}-\mathrm{dS}=5.2268$ and Bayes Factor $=23853.7)(\mathrm{A} \rightarrow \mathrm{T})$.

\section{Discussion}

We provided for the first time a snapshot of the genetic structure and variability among Brazilian $\mathrm{CSDaV}$ isolates collected from both symptomatic and asymptomatic citrus trees grown in fields affected by CSD disease. To date, only two CSDaV genome sequences were fully described, showing $11 \%$ nucleotide diversity between them [23] (GenBank accession no. AY884005 and DQ185573). Both of these well-described CSDaV isolates were obtained from Rangpur lime tissues as rootstock of sweet orange trees collected from the same citrus region assessed in this study [1,24], which is relevant since we can study the evolution of this virus in this CSD-affected area. In the current study, sequence analyses of five regions of the CSDaV genome representing almost $42 \%$ of the whole genome of 31 isolates, sampled from different hosts/plant tissues, showed a low genetic diversity. It is not a surprising finding because genetic stability has been considered as a rule in natural plant virus populations [23] and similar low genetic diversity was previously reported for many other RNA plant viruses [20,25-31]. It has been shown that systemic infections and other events such as host change and transmission can impose bottlenecks, the most common effects of genetic drift, which have been inferred from the low genetic diversity of plant virus populations [32,33] and which might be the reason for the low genetic diversity among the $\mathrm{CSDaV}$ isolates.

The low nucleotide variability observed for the $\mathrm{CP}$, the MT and the RdRP regions of CSDaV genome included in this study suggests that selective pressures in these segments are high to maintain nucleotide and amino acid conservation probably for biological functions [34]. It has been shown that the coat protein $(\mathrm{CP})$ plays critical roles in virus packaging and stability, and interactions with plant host [34]. Similarly, the MT and the RdRP domains play key roles in viral replication, involving mRNA capping and enhanced stability of viral genomes (methyltransferase) [35]; and transcription and replication of RNA virus genomes (RdRP) [36]. On the other hand, the MDR and He regions demonstrated higher nucleotide variability. The MDR segment showed the highest genetic diversity among all studied regions here, and it was the only region that had one site detected as being under positive selection. The MDR segment represents a multi-domain region that contains numerous predicted single domains related to different activities. Interestingly, the MDR was the unique multi-domain region found along the CSDaV genome and was the single region that we could not align with other reference members of the family Tymoviridae. It seems that this region is unique and associated with CSDaV isolates and could be related with some processes of virus adaption [37] to 
a different host or plant tissues. However, at this time, there is no information about the function(s) of this multi-domain, and then further studies are needed to evaluate the real role of this region in CSDaV. Probably because the pair of primers designed for the He region was highly degenerate, we were not able to amplify the He segment in several samples assessed here and it may be possible that the low number of isolates (nine) has influenced the results. From this work, it is clear that there is a genetic diversity between the CSDaV isolates assessed here and the CSDaV references previously reported. The only isolates that showed close phylogenetic relationships with the CSDaV reference isolates were those isolated from the citrus roots, which were also detected as recombinants in this work, pointing the CSDaV reference sequences as the possible parents. Since we know that the CSDaV reference isolates were isolated from rootstock tissues of citrus trees as well [1,24], these results also provide some evidence of the heterogeneous distribution of virus variants at different locations (leaves and roots) within hosts. Other studies have already reported that the diversity of virus populations is different between old and young tissues, suggesting the tree could reflect the chronology of the appearance of virus diversity [38].

Phylogenetic analyses showed two new genetic clades for the CSDaV isolates included in this investigation, and one of them showed higher association with symptomatic trees. Higher nucleotide diversity, $\mathrm{dN} / \mathrm{dS}$ ratio values and number of amino acid changes were found for isolates from symptomatic plants in coding regions located closer to the 5' end region of the CSDaV genome (MT and MDR), whereas coding regions located closer to the $3^{\prime}$ end region showed more conservation. It is important to say that these isolates belonging to these two new genetic clades were all isolated from the citrus leaves, which have been shown to have CSDaV variants, compared to the CSDaV isolates from the roots (this work and the references isolates). It is possible that the CSDaV isolates infecting rootstock tissues were subjected to some positive selection pressures, mainly on the coding regions closer to the $5^{\prime}$ end region, to be able to infect tissues in the citrus canopy, culminating with two different variants of CSDaV, where one of them might be more efficient in infecting CSD-susceptible plants and/or more severe in developing CSD symptoms. Other factors, such as the susceptibility of the citrus rootstock and climate (drought and higher temperature), seem to contribute to the development of the CSD. The confirmed presence of CSDaV in trees grafted on symptomatic and asymptomatic susceptible rootstocks, and symptomatic and asymptomatic tolerant rootstocks, suggest that CSDaV is able to infect a wide host range in CSD-affected regions, but the symptoms are not always developed. The results obtained here do not discard the possibility of a mixed or co-infection of the CSDaV and other virus(es), which was already proposed as a cause of CSD [1]. CSDaV and other members of the genus Marafivirus have been frequently associated in mixed or co-infections in other pathosystems. CSDaV was found to be part of a multiple virus infection in Pinot Noir grapevine [7] and in grapevine Syrah showing decline symptoms [9]. Recently, Villamor et al. [8] found CSDaV infecting California nectarines showing stem-pitting symptoms and also revealed the presence of a new virus of the genus Marafivirus, which shared 70\% of nucleotide sequence similarities to CSDaV, co-infecting these plants. All these results obtained in this investigation could together provide new insights into the role of CSDaV in symptom development in plants affected by CSD and contribute to further epidemiological studies.

Supplementary Materials: The following are available online at http:/ /www.mdpi.com/1999-4915/8/12/330/s1, Figure S1: Graphical summary showing the conserved domains detected from conserved domain search using the CSDaV AY884005 reference sequence as query in the NCBI Conserved Domain Database (CDD), Figure S2: Graphical summary showing the conserved domains detected from conserved domain search using the CSDaV DQ185573 reference sequence as query in the NCBI Conserved Domain Database (CDD), Figure S3: Bootstrap majority rule $(70 \%)$ consensus trees reconstructed by the neighbor joining method for five genomic regions of CSDaV isolates including the consensus sequences from transcriptome sequencing of the symptomatic and asymptomatic plants by using Illumina platform, Figure S4: Bootstrap majority rule (70\%) consensus trees reconstructed by the neighbor joining method for five genomic regions of CSDaV isolates including possible recombinant isolates, field collected and reference sequences, Table S1: Description of domains detected from conserved domain search using the CSDaV AY884005 reference sequence as query. The interval and E-value of each identified domain are shown, Table S2: Description of domains detected from conserved domain search 
using the CSDaV DQ185573 reference sequence as query. The interval and E-value of each identified domain are shown.

Acknowledgments: This work was financially supported by National Institute of Science and Technology of Genomics for Citrus Improvement (INCT Citros), National Council for Scientific and Technological Development (CNPq, Proc. No. 306230/2013-5) and Fundação de Apoio à Pesquisa no Estado de São Paulo (Fapesp, Proc. No. 2008/57909-2). EEM was supported, in part, by National Council for Scientific and Technological Development (CNPq) fellowship and also by Doctoral Sandwich Program Abroad (PDSE/CAPES) fellowship. We wish to thank our lab colleagues from "Centro de Citricultura Sylvio Moreira" for constructive suggestions and discussions and we are grateful to Bryce W. Falk for critical reading of the manuscript and helpful suggestions.

Author Contributions: Emilyn Emy Matsumura, Marcos Antonio Machado and Helvécio Della Coletta Filho conceived and designed the experiments; Emilyn Emy Matsumura and Silvia de Oliveira Dorta performed the experiments; Emilyn Emy Matsumura and Shahideh Nouri analyzed the data; Marcos Antonio Machado contributed with reagents/materials/analysis tools; Emilyn Emy Matsumura, Marcos Antonio Machado, Helvécio Della Coletta Filho and Shahideh Nouri wrote the paper.

Conflicts of Interest: The authors declare no conflict of interest.

\section{References}

1. Maccheroni, W.; Alegria, M.C.; Greggio, C.C.; Piazza, J.P.; Kamla, R.F.; Zacharias, P.R.A.; Bar-Joseph, M.; Kitajima, E.W.; Assumpção, L.C.; Camarotte, G.; et al. Identification and genomic characterization of a new virus (Tymoviridae family) associated with citrus sudden death disease. J. Virol. 2005, 79, 3028-3037. [CrossRef] [PubMed]

2. Mahy, B.W.J.; van Regenmortel, M.H.V. Emerging and reemerging virus diseases of plants. In Desk Encyclopedia of Plant and Fungal Virology, 1st ed.; Mahy, B.W.J., van Regenmortel, M.H.V., Eds.; Elsevier: Amsterdam, The Netherlands, 2009; pp. 412-417.

3. Müller, G.W.; de Negri, J.D.; Aguilar-Vildoso, C.I.; Mattos, D., Jr.; Pompeu, J., Jr.; Teófilo Sobrinho, J.; Machado, M.A. Citrus sudden death: A new citrus disease in Brazil. In XV Conference of the International Organization of Citrus Virologists, Paphos, Chipre, 2001; p. 100.

4. Gomes, C.P.C.; Nagata, T.; Jesus Junior, W.C.; Borges Neto, C.R.; Pappas Junior, G.J.; Martin, D.P. Genetic variation and recombination of RdRp and HSP 70h genes of Citrus tristeza virus isolates from orange trees showing symptoms of citrus sudden death disease. Virol. J. 2008, 5. [CrossRef] [PubMed]

5. Coletta Filho, H.D.; Centro de Citricultura Sylvio Moreira, Instituto Agronômico, Cordeiropolis, SP, Brazil. Personal communication, 2014.

6. Bassanezi, R.B.; Montesino, L.H.; Sanches, A.L.; Spósito, M.B.; Stuchi, E.S.; Barbosa, J.C. Effect of citrus sudden death on yield and quality of sweet orange cultivars in Brazil. Plant Dis. 2007, 91, 1407-1412. [CrossRef]

7. Pantaleo, V.; Moxon, S.; Miozzi, L.; Moulton, V.; Dalmay, T.; Burgyan, J. Identification of grapevine microRNAs and their targets using high throughput sequencing and degradome analysis. Plant J. 2010, 62, 960-976. [PubMed]

8. Villamor, D.E.V.; Mekuria, T.A.; Pillai, S.S.; Eastwell, K.C. High throughput sequencing identifies novel viruses in nectarine: Insights to the etiology of stem pitting disease. Phytopathology 2016, 106, 519-527. [CrossRef] [PubMed]

9. Al Rwahnih, M.; Daubert, S.; Golino, D.; Rowhani, A. Deep sequencing analysis of RNAs from a grapevine showing Syrah decline symptoms reveals a multiple virus infection that includes a novel virus. Virology 2009, 387, 395-401. [CrossRef] [PubMed]

10. Román, M.P.; Cambra, M.; Juarez, J.; Moreno, P.; Duran-Vila, N.; Tanaka, F.A.O.; Alves, E.; Kitajima, E.W.; Yamamoto, P.T.; Bassanezi, R.B.; et al. Sudden death of citrus in Brazil: A graft-transmissible bud union disease. Plant Dis. 2004, 88, 453-467. [CrossRef]

11. Sambrook, J.; Fritsch, E.F.; Maniatis, T. Molecular Cloning: A Laboratory Manual, 2nd ed.; Cold Spring Harbor Laboratory Press: New York, NY, USA, 1989.

12. NCBI: National Center for Biotechnology Information. Available online: http://www.ncbi.nlm.nih.gov/ (accessed on 18 August 2016).

13. Larkin, M.A.; Blackshields, G.; Brown, N.P.; Chenna, R.; Mcgettigan, P.A.; Mcwilliam, H.; Valentin, F.; Wallace, I.M.; Wilm, A.; Lopez, R.; et al. Clustal W and Clustal X version 2.0. Bioinformatics 2007, 23, 2947-2948. [CrossRef] [PubMed] 
14. Tamura, K.; Stecher, G.; Peterson, D.; Filipski, A.; Kumar, S. MEGA6: Molecular Evolutionary Genetics Analysis Version 6.0. Mol. Biol. Evol. 2013, 30, 2725-2729. [CrossRef] [PubMed]

15. FigTree. Available online: http://tree.bio.ed.ac.uk/software/figtree/ (accessed on 18 August 2016).

16. Librado, P.; Rozas, J. DnaSP v5: A software for comprehensive analysis of DNA polymorphism data. Bioinformatics 2009, 25, 1451-1452. [CrossRef] [PubMed]

17. Lole, S.; Bollinger, R.C.; Paranjape, R.S.; Gadkari, D.; Kulkarni, S.S.; Novak, N.G.; Ingersoll, R.; Sheppard, H.W.; Ray, S.C. Fulllength human immunodeficiencey virus Type 1 genomes from subtype Cinfected seroconverters in India, with evidence of intersubtype recombination. J. Virol. 1999, 73, 152-160. [PubMed]

18. Kumar, S.; Tamura, K.; Nei, M. MEGA3: Integrated software for Molecular Evolutionary Genetics Analysis and sequence alignment. Brief. Bioinform. 2004, 5, 150-163. [CrossRef] [PubMed]

19. Datamonkey: Rapid Detection of Positive Selection. Available online: http://www.datamonkey.org/ dataupload.php (accessed on 18 August 2016).

20. Nouri, S.; Arevalo, R.; Falk, B.W.; Groves, R.L. Genetic structure and molecular variability of cucumber mosaic virus isolates in the United States. PLoS ONE 2014. [CrossRef] [PubMed]

21. Matsumura, E.E.; Centro de Citricultura Sylvio Moreira, Instituto Agronômico, Cordeirópolis, SP, Brazil. Electrophoresis agarose gel showing the size of the amplicons obtained from the PCR of the regions MT, MDR, He, RdRP and CP. 2016.

22. Matsumura, E.E.; Coletta-Filho, H.D.; et al. Deep sequencing analysis of RNAs from citrus plants grown in citrus sudden death-affected regions reveals diverse known and putative novel viruses. Virology, submitted.

23. Garcia-Arenal, F.; Fraile, A.; Malpica, J.M. Variability and genetic structure of plant virus populations. Annu. Rev. Phytopathol 2001, 39, 157-186. [CrossRef] [PubMed]

24. Barros, C.C.P. Sequenciamento do Genoma Completo e Expressão Heteróloga da Capa Protéica do Marafivirus Associado a Morte Súbita Dos Citros. Ph.D. Thesis, Universidade Católica de Brasilia, Brasília, Brazil, 2006. (in Portuguese).

25. Kong, P.; Rubio, L.; Polek, M.; Falk, W.B. Population structure and genetic diversity within California Citrus tristeza virus (CTV) isolates. Virus Genes 2000, 21, 139-145. [CrossRef] [PubMed]

26. Rubio, L.; Ayllón, M.A.; Kong, P.; Fernández, A.; Polek, M.; Guerri, J.; Moreno, P.; Falk, B.W. Genetic variation of Citrus tristeza virus isolates from California and Spain: Evidence for mixed infections and recombination. J. Virol. 2001, 75, 8054-8062. [CrossRef] [PubMed]

27. Ale-Agha, G.N.; Rakhshandehroo, F. Detection and molecular variability of fig fleck-associated virus and fig cryptic virus in Iran. J. Phytopathol. 2013, 162, 417-425. [CrossRef]

28. Ogawa, T.; Tomitaka, Y.; Nakagawa, A.; Ohshimab, K. Genetic structure of a population of Potato virus $Y$ inducing potato tuber necrotic ringspot disease in Japan; comparison with North American and European populations. Virus Res. 2008, 131, 199-212. [CrossRef] [PubMed]

29. Seo, J.K.; Ohshima, K.; Lee, H.G.; Son, M.; Choi, H.S.; Lee, S.H.; Sohn, S.H.; Kim, K.H. Molecular variability and genetic structure of the population of Soybean mosaic virus based on the analysis of complete genome sequences. Virology 2009, 393, 91-103. [CrossRef] [PubMed]

30. Moreno, I.M.; Malpica, J.M.; Diaz-Pendon, J.A.; Moriones, E.; Fraile, A.; Garcia-Arenala, F. Variability and genetic structure of the population of watermelon mosaic virus infecting melon in Spain. Virology 2004, 318, 451-460. [CrossRef] [PubMed]

31. Walia, J.J.; Willemsen, A.; Elci, E.; Caglayan, K.; Falk, B.F.; Rubio, L. Genetic variation and possible mechanisms driving the evolution of worldwide Fig mosaic virus isolates. Phytopathology 2013, 104, 108-114. [CrossRef] [PubMed]

32. Ali, A.; Roossinck, M.J. Genetic bottlenecks. In Plant Virus Evolution; Roossinck, M.J., Ed.; Springer: Berlin/Heidelberg, Germany, 2008; pp. 123-131.

33. Li, H.; Roossinck, M.J. Genetic bottlenecks reduce population variation in an experimental RNA virus population. J. Virol. 2004, 78, 10582-10587. [CrossRef] [PubMed]

34. Hammond, R.W.; Kogel, R.; Ramirez, P. Variability of geographically distinct isolates of maize rayado fino virus in Latin America. J. Gen. Virol. 1997, 78, 3153-3159. [CrossRef] [PubMed]

35. Ahola, T.; den Boon, J.A.; Ahlquist, P. Helicase and capping enzyme active site mutations in brome mosaic virus protein 1a cause defects in template recruitment, negative-strand RNA synthesis, and viral RNA capping. J. Virol. 2000, 74, 8803-8811. [CrossRef] [PubMed] 
36. Arnold, J.J.; Cameron, C.E. Structure-function relationships among RNA-dependent RNA polymerases. Curr. Top. Microbiol. Immunol. 2008, 320, 137-156.

37. Moury, B. Differential selection of genes of cucumber mosaic virus subgroups. Mol. Biol. Evol. 2004, 21, 1602-1611. [CrossRef] [PubMed]

38. Jridi, C.; Martin, J.F.; Mareie-Jeanne, V.; Labonne, G.; Blanc, S. Distinct viral populations differentiate and evolve independently in a single perennial host plant. J. Virol. 2006, 80, 2349-2357. [CrossRef] [PubMed]

(C) 2016 by the authors; licensee MDPI, Basel, Switzerland. This article is an open access article distributed under the terms and conditions of the Creative Commons Attribution (CC-BY) license (http://creativecommons.org/licenses/by/4.0/). 